\title{
PENGGUNAAN BERBAGAI JENIS ZPT TERHADAP PERTUMBUHAN VEGETATIF SETEK BATANG JAMBU AIR CITRA (Syzygium aqueum Murr)
}

\author{
Meka Gusti, Olivia Darlis \\ Program Studi Budi Daya Tanaman Hortikultura Jurusan Budi Daya Tanaman Pangan \\ Politeknik Pertanian Negeri Payakumbuh, Jl.Raya Negara KM.7 Tanjung Pati 26271 \\ Kecamatan Harau Kabupaten Lima Puluh Kota Sumatera Barat
}

\begin{abstract}
ABSTRAK
Jambu air Citra (Syzygium aqueum Murr) merupakan salah satu jenis tanaman buah tahunan yang berasal dari Asia Tenggara, ditemukan di daerah Indo Cina dan Indonesia, tersebar ke Malaysia, dan pulau-pulau di Pasifik. Jambu air ini memiliki rasa yang manis dan kandungan vitamin $\mathrm{C}$ zxzxxyang cukup tinggi. Tujuan dari laporan tugas akhir ini adalah mengetahui pengaruh penggunaan berbagai jenis ZPT terhadap pertumbuhan setek batang tanaman jambu air Citra dan mendapatkan jenis ZPT yang terbaik terhadap pertumbuhan setek batang tanaman jambu air Citra. Perbanyakan tanaman jambu air Citra salah satunya dapat dilakukan dengan cara setek. Perbanyakan tanaman secara setek membutuhkan zat pengatur tumbuh (ZPT). Zat pengatur tumbuh yang digunakan meliputi Rapid root, ekstrak daun kelor, ekstrak tauge, dan kontrol. Jumlah sampel yang digunakan untuk masing-masing perlakuan adalah 5 sampel dengan 2 kali ulangan.

Hasil yang diperoleh dari percobaan ini adalah pemberian zat pengatur dari ekstrak tauge memberikan hasil yang terbaik terhadap pertumbuhan setek batang tanaman jambu air Citra, dengan persentase tumbuh $80 \%$, jumlah tunas 2,5 buah, rata-rata jumlah akar 7 buah dan rata-rata panjang akar $6,4 \mathrm{~cm}$. Kesimpulan dari percobaan ini adalah Penggunaan beberapa ZPT berpengaruh terhadap pertumbuhan setek batang tanaman jambu air Citra dan penggunaan ZPT ekstrak tauge memberikan hasil terbaik terhadap pertumbuhan setek batang tanaman jambu air Citra dibandingkan penggunaan ZPT yang lain. Disarankan untuk perbanyakan tanaman jambu air Citra secara setek batang menggunakan ZPT ekstrak tauge.
\end{abstract}

Kata kunci : Zat Pengatur Tumbuh, Ektrak Daun Kelor, Ekstrak Tauge, Rapid Root, Jambu Air Citra

\section{PENDAHULUAN}

\section{Latar Belakang}

Jambu air (Syzygium aqueum Murr) merupakan salah satu jenis tanaman buah tahunan yang berasal dari Asia Tenggara, ditemukan di daerah Indo Cina dan Indonesia, tersebar ke Malaysia, dan pulau-pulau di Pasifik. Jambu air merupakan salah satu jenis buah-buahan yang dikenal oleh masyarakat untuk bahan makanan dan pengobatan beberapa jenis penyakit. Nutrisi yang dimiliki oleh jambu air cukup lengkap. Buah jambu air merupakan sumber kalori, mineral, dan vitamin $\mathrm{C}$. Kandungan nutrisi jambu air baik untuk meningkatkan tenaga (energi) dan meningkatkan sistem ketahanan tubuh (Cahyono, 2010). Perbanyakan tanaman jambu air varietas Citra salah satunya dapat dilakukan dengan cara setek. Setek merupakan teknik perbanyakan vegetatif dengan cara memotong bagian vegetatif untuk ditumbuhkan menjadi tanaman dewasa yang sifatnya mirip dengan sifat induknya (Agung, 2007).

Perbanyakan tanaman secara setek membutuhkan zat pengatur tumbuh (ZPT) untuk menunjang pertumbuhannya, dimana terdapat banyak jenis ZPT yang dapat digunakan, baik ZPT alami maupun yang kimia (Hartman 1997 dalam Masitih 2016). Zat pengatur tumbuh adalah suatu senyawa organik yang berfungsi mempengaruhi proses fisiologis pada tanaman. Zat pengatur tumbuh digunakan untuk memacu pertumbuhan tanaman dan dapat menghambat pertumbuhan tanaman yang tidak dikehendaki. Zat pengatur tumbuh alami yang dapat digunakan adalah ekstrak daun kelor dan ekstrak tauge, dan zat pengatur tumbuh kimia 
yang dapat digunakan adalah Rapid root. Menurut Ashfaq, Ahmed, dan Ramzan, Muhammad. (2013), daun kelor merupakan salah satu bahan organik yang kaya zeatin, sitokinin, askorbat, fenolik, dan mineral seperti $\mathrm{Ca}, \mathrm{K}$, dan $\mathrm{Fe}$ yang memicu pertumbuhan tanaman. Ekstrak tauge memiliki konsentrasi senyawa zat pengatur tumbuh auksin 1,68 ppm, giberelin 39,94 ppm dan sitokinin 96,26 ppm (Ulfa, 2014). Rapid root berfungsi untuk mempercepat pembentukan akar dan memperbanyak akar tanaman (Manurung, 1987). Berdasarkan hal tersebut, maka penulis telah melakukan percobaan dengan judul "Penggunaan Berbagai Jenis ZPT Terhadap Pertumbuhan Vegetatif Setek Batang Jambu Air Citra (Syzygium aqueum Murr) Di BBI PPH Lubuk Minturun Sumatera Barat”.

Tujuan dari percobaan ini adalah untuk :

1. Mengetahui pengaruh penggunaan berbagai jenis ZPT terhadap pertumbuhan setek batang tanaman jambu air Citra.

2. Mendapatkan jenis ZPT yang terbaik terhadap pertumbuhan setek batang tanaman jambu air Citra.

\section{METODE PELAKSANAAN}

\section{Waktu dan Tempat}

Perbanyakan tanaman jambu air Citra dengan setek batang dilakukan bersamaan dengan kegiatan Pengalaman Kerja Praktek Mahasiswa (PKPM) yang telah dilaksanakan selama \pm 3 bulan, pada tanggal 18 Februari sampai 10 Mei 2019. Tempat pelaksanaan di kebun percobaan Balai Benih Induk Padi, Palawija, dan Hortikultura di Lubuk Minturun Padang Sumatera Barat, dengan ketinggian tempat 50 meter di atas permukaan laut (m dpl).

\section{Alat dan Bahan}

Alat yang digunakan terdiri dari cangkul, gerobak, gunting setek, hekter, pisau cutter, gembor, camera $\mathrm{Hp}$, dan alat tulis. Bahan yang digunakan adalah cabang batang tanaman jambu air Citra, ZPT Rapid root, daun kelor, tauge, polybag ukuran $18 \times 25 \mathrm{~cm}$, kertas label, botol bekas, plastik bening, katiron, paranet, tali rafia, tanah, pupuk kandang dan air.

\section{Perlakuan}

Perbanyakan tanaman jambu air Citra dilakukan secara setek batang. Perbanyakan dilakukan menggunakan berbagai jenis Zat Pengatur Tumbuh (ZPT) sebagai perlakuan yang meliputi :
A. Tanpa penggunaan ZPT (kontrol)
B. Penggunaan ZPT Rapid Root
C. Penggunaan Ekstrak Daun Kelor
D. Penggunaan Ekstrak Tauge

Jumlah sampel yang digunakan sebanyak 5 buah untuk masing-masing perlakuan. Ulangan dilakukan sebanyak 2 kali dengan 5 sampel per masing-masing perlakuan. Total keseluruhan setek tanaman jambu air Citra adalah 40 setek.

\section{Pelaksanaan \\ Pembuatan Sungkup Setek}

Kerangka sungkup yang terbuat dari bahan katiron dipasangkan dengan jarak antara kiri-kanan dan depan-belakang kerangka harus sama, agar air hujan tidak menumpuk diatas sungkup setek. Plastik transparan dan paranet sepanjang 7 meter dipasangkan diatas kerangka sungkup setek secara rapi dan padat

\section{Penyiapan Media Tanam}

Media tanam yang digunakan pada setek batang jambu air Citra adalah tanah dan pupuk kandang dengan perbandingan 1:1. Media dicampurkan secara merata kemudian masukkan ke dalam polybag. Total keseluruhan media tanam yang disiapkan adalah 40 polybag.

\section{Persiapan Bahan Setek}

Setek yang dilakukan adalah setek batang. Bagian tanaman yang digunakan sebagai perbanyakan adalah canting yang sudah berkayu, tidak terlalu muda dan tidak terlalu tua, memiliki jumlah mata tunas yang sama, serta bebas hama dan penyakit.

\section{Persiapan Zat Pengatur Tumbuh dan Penanaman}

Zat pengatur tumbuh (ZPT) yang digunakan terdiri dari ZPT kimia dan ZPT alami. ZPT sintesis yang digunakan yaitu Rapid root, sedangkan ZPT alami yang digunakan adalah ekstrak daun kelor dan ekstrak tauge.

\section{a. Tanpa menggunakan ZPT (kontrol) \\ Perlakuan tanpa menggunakan ZPT} (kontrol) diaplikasikan sebanyak 5 sampel setek. Penanaman dilakukan dengan membuat lubang tanam secara tugal sedalam $2-3 \mathrm{~cm}$ pada polybag yang telah disiapkan. Bagian bawah bahan setek ditanam pada polybag tersebut 
kemudian pindahkan setek ke dalam sungkup setek yang telah tersedia.

b. Penggunaan ZPT Rapid root

Perlakuan menggunakan Rapid root diaplikasikan sebanyak 5 sampel setek. Bagian bawah bahan setek dicelupkan ke dalam ZPT rapid root selama 2-3 menit, kemudian kering anginkan sebentar, setelah itu setek ditanam kedalam media tanam dan dipindahkan ke dalam sungkup setek yang telah tersedia.

c. Penggunaan ekstrak daun kelor

Perlakuan penggunaan ekstrak daun kelor diaplikasikan sebanyak 5 sampel setek. Daun kelor sebanyak 100 gram dihaluskan terlebih dahulu dan diambil ekstraknya sebanyak $\pm 50 \mathrm{ml}$, kemudian bagian bawah bahan setek direndam ke dalam ekstrak tersebut selama 2 jam. Selanjutnya bahan setek yang sudah direndam tersebut ditanam pada polybag yang sudah dibuat lubang tanam secara tugal sedalam 2-3 $\mathrm{cm}$ dan padatkan tanah dibagian titik tumbuhnya,kemudian pindahkan ke dalam sungkup setek yang telah tersedia.

d. Penggunaan ekstrak tauge

Perlakuan penggunaan ekstrak tauge diaplikasikan sebanyak 5 sampel setek. Tauge sebanyak 100 gram dihaluskan terlebih dahulu dan diambil ekstraknya sebanyak $\pm 50 \mathrm{ml}$, selanjutnya bagian bawah bahan setek direndamkan ke dalam ekstrak touge tersebut selama 30 menit, tanamkan bahan setek ke dalam polybag dan padatkan tanah dibagian titik tumbuhnya, selanjutnya pindahkan setek ke dalam sungkup setek yang telah tersedia.

\section{Pemeliharaan}

Kegiatan pemeliharaan yang dilakukan diantaranya penyiraman dan pengendalian gulma.

\section{a. Penyiraman}

Penyiraman dilakukan secara rutin satu kali dalam seminggu, menggunakan gembor sampai media tanam dalam kondisi kapasitas lapang. Tujuan dari penyiraman adalah untuk menjaga kelembaban dan setek tidak mengalami kekeringan serta membantu dalam penyerapan unsur hara.

\section{b. Pengendalian gulma}

Jenis gulma yang ditemukan pada polybag perbanyakan tanaman jambu air citra meliputi gulma berdaun lebar dan rumput. Gulma dicabut secara hati-hati agar tidak merusak perakaran setek tanaman dan membuangnya jauh dari lahan perbanyakan.

c. Pengendalian hama dan penyakit
Perbanyakan tanaman jambu air Citra secara setek batang tidak ditemukan hama, melainkan hanya ditemukan penyakit. Penyakit yang ditemukan berupa jamur yang berwarna putih. Pengendaliannya dilakukan secara manual dengan cara mencabut setek tanaman yang telah mati dan membuangnya jauh dari lahan.

\section{Pengamatan}

Pengamatan yang dilakukan pada setek tanaman jambu air Citra adalah :
a. Persentase tumbuh
b. Jumlah tunas
c. Panjang akar
d. Jumlah akar

\section{Hasil}

\section{HASIL DAN PEMBAHASAN}

Pengamatan yang dilakukan terhadap setek batang jambu air Citra dengan perlakuan berbagai jenis ZPT yang berbeda meliputi persentase tumbuh, jumlah tunas, jumlah akar, dan panjang akar, dengan hasil sebagai berikut :

\begin{tabular}{lcccc}
$\begin{array}{c}\text { Tabel 1. Hasil Pertumbuhan Setek Batang Tanaman Jambu } \\
\text { Air Citra Umur }\end{array}$ & 6 Minggu Setelah Tanam \\
\hline \multicolumn{1}{c}{ Perlakuan } & \multicolumn{4}{c}{ Pengamatan } \\
\cline { 2 - 5 } & $\begin{array}{c}\text { Persentase } \\
\text { Tumbuh } \\
(\%)\end{array}$ & $\begin{array}{c}\text { Jumlah } \\
\text { Tunas } \\
\text { (buah) }\end{array}$ & $\begin{array}{c}\text { Panjang } \\
\text { Akar } \\
(\mathrm{cm})\end{array}$ & $\begin{array}{c}\text { Jumlah } \\
\text { Akar } \\
\text { (buah) }\end{array}$ \\
\hline A (Kontrol) & 50 & 1,1 & 2,8 & 2,4 \\
B (Rapid root) & 60 & 1,2 & 3,6 & 3,5 \\
C (Ekstrak daun & 80 & 1,9 & 4,9 & 5,1 \\
$\quad$ kelor) & & & & \\
$\begin{array}{l}\text { D (Ekstrak } \\
\text { tauge) }\end{array}$ & 80 & 2 & 5,1 & 5,6
\end{tabular}

Tabel 1 memperlihatkan bahwa perlakuan kontrol menghasilkan persentase tumbuh sebesar $50 \%$, rata-rata jumlah tunas 1,1 buah, panjang akar 2,8 cm dan jumlah akar 2,4 buah. Perlakuan Rapid Root memiliki persentase tumbuh sebesar $60 \%$, rata-rata jumlah tunas 1,2 buah, panjang akar 3,6 cm dan jumlah akar 3,5 buah. Perlakuan ekstrak daun kelor memiliki persentase tumbuh sebesar 80 $\%$, rata-rata jumlah tunas 1,9 buah, panjang akar 4,9 cm, dan jumlah akar 5,1 buah. Perlakuan ekstrak tauge memiliki persentase tumbuh yaitu $80 \%$,rata-rata jumlah tunas 2 buah, panjang akar 5,1 cm dan jumlah akar 5,6 buah. Perlakuan ekstrak tauge memiliki pertumbuhan yang paling baik di antara perlakuan yang lainnya.

\section{Pembahasan}

Hasil pengamatan terhadap setek batang tanaman jambu air Citra yang telah dilakukan, 
menunjukkan bahwa persentase tumbuh, jumlah tunas, panjang akar, dan jumlah akar terbaik terdapat pada perlakuan ekstrak daun kelor dan ekstrak tauge. Parameter pertumbuhan setek batang jambu air Citra disajikan pada tabel 1.

Perlakuan ekstrak daun kelor dan ekstrak tauge menghasilkan persentase tumbuh setek batang jambu air Citra lebih tinggi dibandingkan dengan perlakuan kontrol dan rapid root. Rendahnya persentase tumbuh pada perlakuan kontrol disebabkan karena tidak adanya pemberian ZPT, sehingga zat perangsang tumbuh terutama untuk tunas, tidak sebanyak yang ada pada perlakuan, dan setek tidak tumbuh dengan baik. Menurut Anonim (2008), faktor yang mempengaruhi keberhasilan setek salah satunya faktor luar yaitu, media tanam. Media tanam yang mengalami kekeringan dapat mempengaruhi keberhasilan setek tanaman. Persentase tumbuh perlakuan ekstrak daun kelor dan ekstrak tauge lebih tinggi, dikarenakan ekstrak daun kelor dan ekstrak tauge sama-sama memiliki hormon sitikonin yang cukup tinggi. Hormon sitokinin berfungsi sebagai pengatur pertumbuhan dan diferensissi sel, serta merangsang pembentuan tunas, sehingga setek dapat tumbuh dengan baik. Menurut davies (2010), sitokinin memiliki fungsi sebagai penginduksi pembelahan sel, menginduksi pembentukan tunas, menstimulasi pembentukan tunas lateral, pembentukan daun, dan penundaan penuaan daun.

Persentase tumbuh setek tanaman jambu air Citra diamati sampai 6 minggu setelah tanam. Perlakuan kontrol memiliki persentasi tumbuh yang paling kecil yaitu 50\% dan perlakuan ekstrak daun kelor serta perlakuan ekstrak tauge memiliki persentase tumbuh paling tinggi yaitu $80 \%$. Semua perlakuan tidak ada yang memiliki persentase tumbuh mencapai $100 \%$. Hal ini dikarenakan beberapa tanaman mati setelah berumur 4, 5, 6 minggu setelah tanam. Kondisi tersebut disebabkan oleh beberapa hal seperti, serangan penyakit berupa jamur dan keadaan suhu yang cukup tinggi. Penyakit berupa jamur ini disebabkan oleh keadaan media tanam yang lembab, sehingga perkembangan jamur terjadi dengan cepat dan mengakibatkan setek menjadi mati. Keadaan suhu yang cukup tinggi mengakibatkan bahan setek kehabisan cadangan makanan dan kekeringan, sehingga setek menjadi mati. Sukarmin (2018) menyatakan bahwa laju pertumbuhan tunas dan daun pada setek tidak diimbangi dengan laju pertumbuhan akar, sehingga perkembangan tunas dan daun hanya memanfaatkan cadangan makanan pada batang yang dijadikan bahan setek, yang kemudian manyebabkan tanaman mati perlahan akibat kehabisan makanan. Selain itu perbedaan persentase tumbuh juga dipengaruhi oleh beberapa faktor, seperti faktor internal dan faktor eksternal.

Faktor internal merupakan faktor yang berasal dari bibit atau tanaman itu sendiri,faktor internal yang mempengaruhi diantaranya, bibit yang digunakan adalah bibit yang sehat, cukup umur, serta memiliki bagian tanaman yang sempurna (daun, batang, akar). Faktor eksternal merupakan faktor yang berasal dari lingkungan luar tempat tumbuh tanaman. Faktor eksternal terdiri atas dua komponen, yaitu biotik dan abiotik. Kompenen biotik meliputi, hama, penyakit, mikroorganisme dan manusia, sedangkan komponen abiotik meliputi, suhu, cahaya matahari, angin, tanah, dan kelembaban.

Hasil pengamatan jumlah tunas menunjukkan bahwa dari ke tiga percobaan, untuk perlakuan ekstrak tauge memberikan respon yang terbaik dibandingkan dengan perlakuan ektrak daun kelor, kontrol dan rapid root. Keadaan ini dikarenakan, ekstrak tauge mengandung hormon sitokinin yang cukup tinggi, sehingga pembentukan tunas dapat tumbuh dengan baik. Sitokinin memiliki fungsi sebagai penginduksi pembelahan sel, morfogenesis, termasuk inisiasi batang dan induksi pembentukan tunas, menstimulasi pertumbuhan tunas lateral, pembentangan daun, penundaan penuaan daun, menstimulasi pembukaan stomata pada beberapa spesies dan berperan dalam perkembangan kloroplas karena menstimulasi akumulasi klorofil dan konversi etioplast menjadi kloroplast (Davies, 2010).

Perlakuan ekstrak daun kelor juga memberikan hasil yang baik, terhadap jumlah tunas karena ekstak daun kelor mengandung hormon sitokinin yang dapat meningkatkan pertumbuhan tunas. Menurut Samnudin (2009), hormon sitokinin pada ekstrak daun kelor berfungsi untuk merangsang pembelahan sel, menunda penuaan jaringan tanaman, dan mamacu pertumbuhan tunas, sehingga pemberian ekstrak daun kelor mampu memberikan hasil yang baik terhadap setek batang tanaman jambu air Citra setelah pemberian ekstrak tauge. 
Jumlah tunas untuk semua perlakuan berdasarkan data pengamatan kurang mengalami peningkatan jumlah yang signifikan. Penambahan jumlah tunas hanya terdapat pada beberapa perlakuan, seperti perlakuan $\mathrm{C}$ dan $\mathrm{D}$ yang mengalami peningkatan jumlah tunas dari minggu ke 4 sampai minggu ke 6. Rata-ata jumlah tunas terbanyak berdasarkan hasil pengamatan terdapat pada perlakuan D (eksrak tauge) yaitu 2 buah, kemudian perlakuan $\mathrm{C}$ (ekstrak daun kelor) yaitu 1,9 buah. Perlakuan kontrol memiliki rata-rata jumlah tunas sebanyak 1,1 buah, dan perlakuan rapid root sebanyak 1,2 buah.

Pertumbuhan setek yang baik, biasanya diawali dengan pertumbuhan akar terlebih dahulu, agar organ vegetatif lainnya dapat berkembang dengan baik dan memiliki keseimbangan pertumbuhan antara akar dan tunas. Huik (2004), menyatakan bahwa terbentuknya akar pada setek merupakan indikasi keberhasilan dari setek. Beberapa bagian tanaman juga memiliki kandungan senyawa/hormon yang berbeda dan memberikan pengaruh pertumbuhan yang berbeda pula terhadap setek tanaman.

Hasil pengamatan untuk panjang akar dan jumlah akar dengan perlakuan ekstrak daun kelor dan ekstak tauge memberikan hasil yang tidak jauh berbeda. Jumlah akar dan panjang akar tertinggi terdapat pada perlakuan ekstrak tauge. Kondisi ini dikarenakan ekstrak tauge mengandung hormon auksin yang berfungsi untuk meningkatkan dan mempercepat terbentuknya akar pada setek tanaman. Auksin pada tauge berfungsi untuk membantu dalam proses mempercepat pertumbuhan, baik pertumbuhan akar maupun batang, dan membantu dalam proses pembelahan sel (Astawan,2005). Pemberian ekstrak tauge memberikan hasil yang baik untuk pertumbuhan setek batang tanaman jambu air Citra, terutama pada pertumbuhan akar tanaman seperti jumlah dan panjang akar. Ekstrak kecambah/tauge mengandung asam amino esensial seperti triptofan yang merupakan prekusor proses biosintesis IAA.

Pemberian ekstrak daun kelor juga memberikan hasil yang baik terhadap jumlah akar dan panjang akar tanaman jambu air Citra setelah perlakuan ekstrak tauge. Ekstrak daun kelor dapat digunakan untuk mempercepat pertumbuhan tanaman secara alami, karena daun kelor kaya akan zeatin, sitokinin dan askorbat yang dapat memicu pertumbuhan tanaman. Ekstrak daun kelor juga mengandung senyawa fitokimia seperti flavonoid, saponin, dan tanin yang berperan sebagai antibakteri sehingga pertumbuhan setek dapat berlajan dengan baik.

Panjang akar dan jumlah akar terbaik diberikan oleh perlakuan $\mathrm{C}$ (ekstrak daun kelor) dan D (ekstrak tauge). Panjang akar perlakuan C setelah di rata-ratakan adalah $4,9 \mathrm{~cm}$ dan perlakuan D setelah dirata-ratakan adalah 5,1 $\mathrm{cm}$. Pertumbuhan akar dapat dipercepat dengan pemberian zat pengatur tumbuh yaitu auksin, yang bertujuan untuk merangsang pertumbuhan akar, sehingga tanaman dapat tumbuh dengan baik. Hormon auksin banyak terdapat pada ekstrak tauge, sehingga perlakuan D (ekstrak tauge) memberikan hasil yang terbaik untuk parameter panjang akar dan jumlah akar.

Perlakuan kontrol memberikan hasil yang lebih rendah pada persentase tumbuh, jumlah tunas, jumlah akar, dan panjang akar dibandingkan dengan perlakuan rapid root, ekstrak daun kelor, dan ekstrak tauge. Kondisi tersebut disebabkan karena pada perlakuan kontrol tidak diberikan zat pengatur tumbuh yang dapat mempengaruhi pertumbuhan tunas dan pertumbuhan akar. Tanaman yang tidak diberikan zat pengatu tumbuh (kontrol) pertumbuhannya untuk tunas dan akar lebih lambat dibandingkan tanaman yang diberikan perlakuan. Menurut Gaba (2005), zat pengatur tumbuh berperan penting mengontrol proses biologis dalam jaringan tanaman.

\section{Kesimpulan}

\section{KESIMPULAN DAN SARAN}

Berdasarkan hasil dan pembahasan yang telah dipaparkan maka dapat diambil kesimpulan sebagai berkut :

1. Penggunaan beberapa ZPT berpengaruh terhadap pertumbuhan setek batang tanaman jambu air Citra.

2. Penggunaan ZPT ekstrak tauge memberikan hasil terbaik terhadap pertumbuhan setek batang tanaman jambu air Citra.

\section{Saran}

Berdasarkan kesimpulan disarankan untuk perbanyakan tanaman jambu air Citra secara setek batang menggunakan ZPT ekstrak tauge.

\section{DAFTAR PUSTAKA}


Adinugraha. 2007. Teknik pembibitan dan perbanyakan vegetatif tanaman hias. Bogor. World Agroforestry Centre

Amilah dan Y. Astuti. 2006. Pengaruh konsentrasi ekstrak touge dan kacang hijau pada media vacin and went (VW) terhadap pertumbuhan kecambah anggrek bulan (Phalaeonopsis amabilis L.). Bulletin Penelitian (9): 78-96.

Agung, S. 2007. Kunci Sukses Memperbanyak Tanaman. Jakarta: PT. agromedia Pustaka.

Anonim 2012. Memilih Jenis Jambu Air Terbaik untuk Dibudidayakan, diunduh 28 februari 2019

Anonim. 2015. Buku Petunjuk Praktikum Teknologi Budidaya Tanaman UPN "Veteran" Yogyakarta.

Amilah dan Astuti. 2006. Pengaruh Konsentrasi Ekstrak Tauge Dan Kacang Hijau Pada Media Vacin And Went (VW) Terhadap Pertumbuhan Kacembah Anggrek Bulan phalanenopsis amabilis L. Bulletin Penelitian.

Ashfaq, Ahmed, dan Ramzan, Muhammad. (2013). Effect of Job Stress on Employee Job Performance A Study on Banking Sector of Pakistan. IOSR Journal of Business and Management, 11(6), 61-68.

Briggs, G. B. dan C. L. Calvin. 2011. Indoors Plants. John Wiley and Sons. New York. $516 \mathrm{p}$

Cahyono B. 2010. Sukses Budidaya Jambu Air di Pekarangan dan Perkebunan. Yogyakarta: Lily Publisher.

Campbell, 2005. Biologi Edisi kelima Jilid 2, Erlangga, Jakarta.

Danu dan Nurhasybi. 2003. Potensi Benih Generatif Dan Vegetatif Dalam Pembangunan Hutan Taman. Makalah Temu Lampung Dan Ekspose Hasil Penelitian UPT Badan Litbang Kehutanan.

Davies, P. J. 2010. Plant Hormones. Springer. New York. p 257-258.

Dewi, Singgah Sima. 2014. Laporan Praktikum TBT smt 1 perbanyakan. http://singgahsimadewi.blogspot.com/20 14/12/laporan-praktikum-tbt-smt-1perbanyakan.html?m=1.

Emongor, V.E. 2015. Effects of Moringa (Moringaoleifera) leaf extract on growth, yield and yield components of snap beans (Phaseolus vulgaris). British
Journal of Applied Science and Technology. 6(2): 114-122.

Gaba, V.P. 2005. Plant Growth Regulator. In R.N. Trigiano Ang D.J. Gray (eds) Plant Tissue Culture And Development. CRC Press. London.

Gardner, F. P., R.B. Pearce, dan R. L. Mitchell.1991. Physiology of Crop Plants. Universitas Indonesia Press. Jakarta.

Hartmann, H. T., D. E. Kester, F. T. Davies, dan R. L. Geneve. 1997. Plant Propagation (6th Edition) by Cutting. Upper Saddle River. New Jersey.

Henuhili V., (2010). Budidaya Dan Peningkatan Nilai Jual Jambu Air Di Wilayah Pedukuhan Jogotirto Desa Krasakan Kecamatan Berbah Kabupaten Sleman, Laporan Hasil Penelitian, FMIPA Unifersitas Negeri Yogyakarta.

Huik. E.M. 2004. Pengaruh Rootone F dan Ukuran Diameter Setek Terhadap Pertumbuhan Setek Batang Jati. Agronomy Jurnal Vol. 3(1) : 12-15.

Junaidi, Wawan, 2008, Pengaruh Auksin Terhadap Pemanjangan Jaringan, http://wawan-

junaidi.blogspot.com/, Diakses pada hari Jum'at tanggal 2 Oktober 2012 pukul 19.00 WITA.

Krisnadi, A. D. 2015. Kelor Super Nutrisi. Pusat Informasi dan Pengembangan Tanaman Kelor Indonesia. $152 \mathrm{hlm}$.

Manurung, S.O. 1987. Status dan Potensi Zat Pengatur Tumbuh serta Prospek Penggunaan Rootone-F dalam Perbanyakan Tanaman. Buku. Departemen Kehutanan. Jakarta. 61 p.

Prakash, A., (2001). Antioxsidant Activity. Medallion Laboratories-Analitycal Progress.

Prihatman, K. 2000. Jambu Air (Eugenia aquea Burm). Kantor DeputiMenegristek Bidang Pendayagunaan dan Pemasyarakatan Ilmu Pengetahuan dan Teknologi.Jambu air_pdf.05 Maret 2018.

Salisbury, F.B. dan W.C., Ross. 1995. Fisiologi Tumbuhan Jilid Tiga, Penerjemah Lukman, D. R. Dan Sumaryono. Penerbit ITB, Bandung.

Samnudin, S. 2009. Pengaruh kombinasi auksin-sitokinin terhadap pertumbuhan buah naga. Media Litbang Sulteng. 2 (1): $62-66$. 
Sari, Ayu Nurwinda. 2015. Laporan DasarDasar Agronomi Acara I.ayunurwindapert.blogspot.com/2015/02 /laporan-dasar-dasar-agronomi-acarai.html?m=1. Diakses pada hari Selasa, 24 November 2015 pukul 07.08 WIB.

Sinha, R. K. 2004. Modern Plant Physiology. CRC Press. Boca Raton. p 482-484.

Srivastava, L. M. 2002. Plant Growth and Development. Academic Press. London. P. 191-192.

Sukarmin. 2018. Hasilwawancarapribadi. BalitbuTropikaSolok.

Ulfa, Fachirah. 2014. Peran Senyawa Bioaktif Tanaman Sebagai Zat Pengatur Tumbuh Dalam Memacu Pertumbuhan Umbi Mini Kentang (Solanum tuberosum, L.) Pada Sistem Budidaya Aeroponik. Disertasi Program Studi Ilmu Pertanian Pasca Sarjana. Universitas Hasanudin Makasar.

Wudianto, R. 2012. Membuat Setek, Cangkong, dan Okulasi. Penebar Swadaya : Jakarta. 